\title{
ISOLASI DAN IDENTIFIKASI BAKTERI ASAM LAKTAT PENGHASIL INHIBITOR ENZIM HMG-KoA REDUKTASE DARI BEKASAM SEBAGAI AGEN PEREDUKSI KOLESTEROL
}

\author{
Isolation and Identification of Lactic Acid Bacteria that Produced HMG-CoA Reductase Enzyme Inhibitor \\ from Bekasam as A Cholesterol Reduction Agent
}

\author{
Rinto $^{1,2}$, Ratih Dewanti ${ }^{2}$, Sedarnawati Yasni², Maggy Thenawidjaja Suhartono ${ }^{2}$ \\ ${ }^{1}$ Program Studi Teknologi Hasil Perikanan, Fakultas Pertanian, Universitas Sriwijaya, Jl. Palembang-Prabumulih Km. 32 , \\ Indralaya, Ogan Ilir, Sumatera Selatan 30862 \\ ${ }^{2}$ Departemen Ilmu dan Teknologi Pangan, Fakultas Teknologi Pertanian, \\ Institut Pertanian Bogor, Kampus Darmaga Bogor 16680 \\ Email: mthenawidjaja@yahoo.com
}

\begin{abstract}
ABSTRAK
Penelitian ini bertujuan memperoleh bakteri penghasil statin sebagai inhibitor enzim HMG-KoA reduktase (HMGR), penghambat sintesis kolesterol. Tahapan penelitian yang dilakukan adalah isolasi bakteri yang resisten terhadap compactin dan lovastatin, produksi statin, uji penghambatan ekstrak dari kultur bakteri terhadap HMG-KoA reduktase dan identifikasi bakteri. Hasil penelitian menunjukan bahwa dari 20 isolat bakteri yang resisten terhadap compactin maupun lovastatin, terdapat 5 isolat bakteri yang potensial menghasilkan statin, yaitu isolat L3.3.4; C3.4.2; C3.3.5; C3.4.4 dan L3.3.3; dengan kandungan statin berturut-turut adalah 9.491; 1,536; 0,065, 0,060, dan 0,040 ppm. Seleksi terhadap 5 isolat menghasilkan 2 bakteri yang mempunyai kemampuan penghambatan terhadap aktivitas enzim HMGR yaitu Lactobacillus acidophilus dan Lactobacillus delbruckii sp. delbruckii dengan kemampuan penghambatan berturut-turut adalah $66,67 \%$ dan $58,33 \%$.
\end{abstract}

Kata kunci: L. acidophilus, L. delbrucki, inhibitor HMGR, kolesterol, bekasam

\begin{abstract}
The purpose of this research was to obtain statins producer bacteria as a HMG-CoA reductase (HMGR) enzyme inhibitor to reduced cholesterol biosynthesis. Stages of this research were the isolation of compactin and lovastatin resistant bacteria, statin production, analysis of culture extracts to inhibition of HMG-CoA reductase and identification of bacteria. The results showed that the 20 isolates of compactin and lovastatin resistant bacteria, there are 5 bacterial isolates produced statins. They were L3.3.4; C3.4.2; C3.3.5; C3.4.4 and L3.3.3; with the statins content were 9.491; 1.536; 0.065 ; 0.060 ; and $0.040 \mathrm{ppm}$. Selection of the 5 bacterial isolates resulted 2 bacteria which had inhibition ability to HMGR enzyme activity. They were Lactobacillus acidophilus and Lactobacillus delbruckii sp. delbruckii with inhibitory ability were $66.67 \%$ and $58.33 \%$, respectively.
\end{abstract}

Keywords: L. acidophilus, L. delbrucki, HMGR inhibitor, cholesterol, bekasam

\section{PENDAHULUAN}

Insiden penyakit jantung merupakan penyebab kematian utama di negara maju maupun negara berkembang. Sebanyak 90\% penyakit jantung diawali oleh timbulnya aterosklerosis. Aterosklerosis merupakan akumulasi kolesterol dalam lapisan intima arteri sebagai akibat tingginya kolesterol darah atau disebut hiperkolesterolemia. Hiperkolesterolemia dipengaruhi oleh konsumsi makanan yang mengandung kolesterol tinggi maupun sintesis kolesterol dalam hati. Pola makan manusia saat ini yang banyak mengkonsumsi makanan berkolesterol tinggi dapat menyebabkan peningkatan kadar kolesterol darah, sehingga kasus hiperkolesterolemia dan penyakit jantung semakin meningkat (Delima dkk. 2009).

Penurunan kolesterol darah pada penderita hiperkolesterolemia dapat dilakukan dengan membatasi 
biosintesis kolesterol dalam hati (Kirana, 2005). Pembatasan biosintesis kolesterol dapat dilakukan dengan menghambat aktivitas enzim 3-hidroksi-3-metilglutaril koenzim A (HMG-KoA) reduktase (HMGR). HMGR merupakan enzim kunci yang berperan dalam awal sintesis kolesterol dengan merombak HMG-KoA menjadi mevalonat yang bersifat irreversible (Burg dan Espenshade, 2011).

Statin merupakan komponen bioaktif yang sangat signifikan menghambat biosintesis kolesterol dengan menghambat aktivitas enzim HMGR. Statin merupakan komponen bioaktif golongan poliketida yang disintesis oleh beberapa mikroorganisme (Chakravarti dan Sahai, 2004). Lovastatin, simvastatin, compactin/mevastatin dan pravastatin merupakan statin alami yang dihasilkan oleh mikroorganisme. Beberapa mikroorganisme penghasil statin adalah Penicillium citrinum (compactin), Aspergillus terreus (lovastatin dan simvastatin), Streptomyces carbophilus, Actinomadura, Bacillus megaterium (pravastatin) (BarriosGonzales dan Miranda, 2010). Bekasam yang merupakan salah satu produk fermentasi ikan diketahui mengandung statin dan mampu menurunkan aktivitas enzim HMGR (Rinto dkk., 2013), oleh karena itu dalam penelitian ini dilakukan isolasi dan identifikasi mikroorganisme dari bekasam yang menghasilkan statin sebagai inhibitor HMG-KoA reduktase (HMGR).

\section{METODE PENELITIAN}

\section{Bahan dan Alat}

Bahan utama yang digunakan terdiri dari 5 jenis bekasam dari produsen yang berbeda. Media MRS broth, compactin dan lovastatin (Sigma Aldrich), API $50 \mathrm{CH}$ dan CHL, syringe filter 0.45 um (Whatman), HMGCoA reductase assay kit $\neq$ CS1090 (Sigma-Aldrich) serta bahan-bahan kimia yang digunakan untuk ekstraksi dan analisis statin menggunakan Spektrofotometer UV-Vis dan HPLC. Alat utama yang digunakan adalah Spektrofotometer UV-Vis Shimadzu UV-1800, HPLC dengan kolom C-18, sentrifugasi dengan pendingin dan inkubator.

\section{Cara Kerja}

Isolasi dan skrining bakteri penghasil statin (Chen dkk., 2006). Skrining bakteri penghasil inhibitor HMGR dilakukan menggunakan compactin/lovastatin sebagai penseleksi dalam media kultur bakteri. Bakteri yang mampu memproduksi inhibitor HMGR (statin) merupakan bakteri yang tahan terhadap compactin maupun lovastatin. Sebanyak $10 \mathrm{~g}$ bekasam dilarutkan dalam $90 \mathrm{~mL}$ akuades steril dan dihomogenisasi, $1 \mathrm{~mL}$ larutan berisi bakteri ditumbuhkan ke dalam $9 \mathrm{~mL}$ media MRS cair kemudian ditumbuhkan pada suhu $35^{\circ} \mathrm{C}$ selama 48 jam. Setelah itu $1 \mathrm{~mL}$ kultur dipindahkan kedalam $9 \mathrm{~mL}$ media MRS cair berisi compactin $100 \mu \mathrm{g} / \mathrm{mL}$ maupun lovastatin $1 \mathrm{mg} / \mathrm{mL}$ dan diinkubasi pada $35^{\circ} \mathrm{C}$ selama 5 hari. Kultur yang berusia 5 hari diukur absorbansinya untuk menentukan kultur bakteri yang paling tahan terhadap compactin/lovastatin dan cepat mengalami pertumbuhan.

Kultur bakteri yang paling tahan dan dapat tumbuh dengan optimum, diremajakan dalam media MRS cair dan diinkubasi selama 24 jam. Kemudian, sebanyak $1 \mathrm{~mL}$ kultur yang berumur 24 jam dipindahkan dalam media MRS agar berisi compactin $150 \mu \mathrm{g} / \mathrm{mL}$ dan lovastatin $2 \mathrm{mg} / \mathrm{mL}$ dan dinkubasi pada $35^{\circ} \mathrm{C}$ selama 2 hari untuk diseleksi kembali. Koloni bakteri yang tumbuh pada media MRS agar merupakan bakteri yang resisten terhadap statin. Bakteri yang resisten terhadap statin digunakan untuk uji produksi statin. Hasil produksi statin oleh kultur bakteri dianalisis menggunakan spektrofotometer dan HPLC.

Analisis statin (Abe dkk., (2002) dan Harsha dkk., (2013)). Kultur cair (5 mL) ditambah $\mathrm{NaOH} 2 \mathrm{~N}$ (5 $\mathrm{mL}$ ), di-shaking $180 \mathrm{rpm}$ selama 1 jam pada rotary shaker. Residu difilter dengan kertas saring dan syringe filter 0.45 um, disentrifugasi pada $6000 \mathrm{rpm}, 4^{\circ} \mathrm{C}$ selama 15 menit, kemudian supernatan dikumpulkan. Supernatan digunakan untuk analisis statin menggunakan spektrofotometer dan HPLC. Analisis statin menggunakan spektrofotometer dilakukan dengan mengambil $1 \mathrm{~mL}$ supernatan dan dilarutkan dalam $9 \mathrm{~mL}$ methanol, dihomogenisasi dan dianalisis dengan spektrofotometer pada panjang gelombang $238 \mathrm{~nm}$ (Abe dkk., 2002).

Analisis menggunakan HPLC dilakukan terhadap 5 isolat bakteri terbaik yang menghasilkan statin berdasarkan analisis menggunakan spektrofotometer. Supernatan hasil sentrifugasi digunakan untuk analisis menggunakan HPLC. Fase gerak yang digunakan adalah metanol, kolom C-18 dan pengukuran pada panjang gelombang $238 \mathrm{~nm}$ (Harsha dkk., 2013).

Analisis penghambatan statin terhadap enzim HMGR (Lachenmeier dkk., 2012). Kultur cair disentrifugasi pada $6000 \mathrm{rpm}$ selama 15 menit kemudian disaring dengan syringe filter $0.45 \mu 1$. Supernatan dipisahkan, digunakan untuk analisis penghambatan kultur bakteri terhadap enzim HMGKoA reduktase (HMGR) menggunakan HMGCoA reductase assay kit $\neq C S 1090$ (Sigma-Aldrich). Prosedur uji dilakukan dengan mengikuti instruksi sesuai dengan prosedur dari Sigma-aldrich. Semua reagen yang akan digunakan (Enzim HMG-CoA reductase (HMGR), buffer, NADPH, subtrat HMG-CoA, dan pravastatin dicairkan dalam refrigerator ataupun dalam es untuk menjaga suhu tetap dingin. Sebelum dimulai, spektrofotometer disetting pada panjang gelombang 
$340 \mathrm{~nm}$. Reagen ditambahkan sesuai dengan prosedur seperti yang terlihat pada table berikut ini (Lachenmeier dkk., 2012).

Tabel 1. Kosentrasi reagen pada uji inhibisi aktivitas HMGR

\begin{tabular}{lccccc}
\hline Sampel & Buffer & Pravastatin & NADPH & HMG-KoA & HMGR \\
\hline Blanko & $920 \mu \mathrm{L}$ & - & $20 \mu \mathrm{L}$ & $60 \mu \mathrm{L}$ & - \\
Activitas & $915 \mu \mathrm{L}$ & - & $20 \mu \mathrm{L}$ & $60 \mu \mathrm{L}$ & $5 \mu \mathrm{L}$ \\
Inhibisi & $910 \mu \mathrm{L}$ & $5 \mu \mathrm{L}$ & $20 \mu \mathrm{L}$ & $60 \mu \mathrm{L}$ & $5 \mu \mathrm{L}$ \\
\hline
\end{tabular}

Setiap $1 \mathrm{~mL}$ sampel, dibaca dengan spektrofotometer (340 nm) setiap menit selama 5 menit. Aktivitas enzim dihitung dengan persamaan:

$$
\text { Unit/mgP }=\frac{\left(\Delta \mathrm{A}_{340} / \mathrm{min}_{\text {sampel }}-\Delta \mathrm{A}_{340} / \mathrm{min}_{\text {blanko }}\right) \times \mathrm{TV}}{12,44 \times \mathrm{V} \times 0,6 \times \mathrm{LP}}
$$

Keterangan:

1. $12,44=2$ kebutuhan NADPH selama reaksi. (koefisien untuk NADPH pada $340 \mathrm{~nm}$ adalah $6,22 / \mathrm{mM} . \mathrm{cm})$

2. $\mathrm{TV}=$ Volume total reaksi $(1 \mathrm{~mL})$

3. $\mathrm{V}=$ Volume enzim yang digunakan

4. $0,6=$ Kosentrasi enzim dalam mg-protein $(\mathrm{mgP}) / \mathrm{mL}$

5. LP = Ligh path (1 untuk cuvettes)

Identifikasi bakteri penghasil statin (Desniar dkk., 2012). Tahapan penelitian ini bertujuan mengetahui genus bakteri yang menghasilkan statin. Karakterisasi bakteri yang diamati meliputi bentuk dan pewarnaan gram, uji katalase, uji motilitas serta uji pertumbuhan bakteri pada berbagai suhu. Identifikasi terhadap bakteri dilakukan dengan menggunakan 50 jenis gula yang menghasilkan asam dengan menggunakan kit mikrobiologi standar API 50CH dan API 50CHL (Desniar dkk., 2012).

\section{HASIL DAN PEMBAHASAN}

\section{Bakteri Resisten terhadap Statin}

Hasil isolasi menunjukan adanya bakteri dari bekasam yang tahan terhadap compactin dan lovastatin. Beberapa bakteri yang tahan terhadap compactin maupun lovastatin dimungkinkan mampu menghasilkan jenis statin tertentu. Chen dkk., 2006 menyebutkan bahwa beberapa bakteri yang resisten terhadap compactin, yaitu Streptomyces roseochromogenus, S. carbophilus, S. halstedii, Actinomadura sp., Streptomyces sp, terbukti menghasilkan salah satu jenis statin (pravastatin). Selain itu, Amycolatopsis sp., yang resisten terhadap lovastatin mampu menghasilkan wuxistatin (Zhuge dkk., 2008). Kemampuan bakteri yang tahan terhadap compactin ataupun lovastatin untuk tumbuh dan berkembang dapat diamati dengan melihat adanya peningkatan nilai Optical Density (OD) pada kultur yang ditumbuhkan (Tabel 2). Semakin besar nilai OD menunjukan semakin banyak bakteri resisten yang tumbuh selama inkubasi pada media MRS cair.

Nilai Optical Density pada Tabel 2 menunjukkan bahwa pada kultur bakteri dari bekasam terdapat mikroorganisme yang tahan terhadap compactin maupun lovastatin. Hal ini dibuktikan dengan adanya peningkatan nilai OD dibandingkan dengan kontrol (media MRS). Rata-rata nilai OD pada media dengan penambahan compactin lebih rendah dibandingkan dengan lovastatin, sehingga compactin lebih efektif dalam menseleksi bakteri yang resisten terhadap statin dibandingkan lovastatin.Kultur bakteri C3 dan L3 memiliki pertumbuhan terbaik dibandingkan dengan kultur yang lainnya, kultur bakteri C3 dan L3 paling resisten terhadap statin (compactin dan lovastatin). Kedua kultur bakteri tersebut berasal dari jenis bekasam yang sama yaitu bekasam yang terbuat dari ikan seluang. Kondisi ini menunjukkan bahwa jumlah bakteri yang resisten terhadap compactin/lovastatin lebih banyak terdapat pada bekasam ikan seluang dibandingkan dengan bekasam ikan gabus. Hal ini juga sejalan dengan jumlah statin (compactin, lovastatin, simvastatin, dan pravastatin) pada bekasam ikan seluang yang lebih tinggi dibandingkan dengan lainnya (Rinto dkk. 2013). Kultur C3 dan L3 dari bekasam ikan seluang digunakan untuk tahapan screening selanjutnya.

Tabel 2. Nilai Optical Density (OD) kultur bakteri dari bekasam pada media MRS dengan penambahan compactin maupun lovastatin sebagai agen penseleksi inkubasi pada $35^{\circ} \mathrm{C}$ selama 5 hari

\begin{tabular}{ccccccccccc}
\hline Kultur & Kontrol (MRS cair) & C1 & C2 & C3 & C4 & L1 & L2 & L3 & L4 \\
\hline OD $_{620}$ & 0.087 & 0.334 & 0.269 & 0.378 & 0.262 & 0.391 & 0.348 & 0.412 & 0.386 \\
\hline
\end{tabular}

Ket: $\mathrm{C}$ : kultur bakteri dari bekasam dengan media penseleksi MRS + compactin

$\mathrm{L}$ : kultur bakteri dari bekasam dengan media penseleksi MRS + lovastatin 
Tabel 3. Morfologi bakteri yang resisten terhadap compactin dan lovastatin

\begin{tabular}{ccl}
\hline No. & Isolat & Bentuk sel \\
\hline 1 & C3.4.1 & Coccus single \\
2 & C3.4.2 & Batang \\
3 & C3.4.3 & Coccus gerombol \\
4 & C3.4.4 & Coccus berderet \\
5 & C3.4.5 & Coccus \\
6 & C3.3.1 & Coccus tetrat \\
7 & C3.3.2 & Coccus \\
8 & C3.3.3 & Coccus single \\
9 & C3.3.4 & Coccus single \\
10 & C3.3.5 & Batang \\
11 & L3.4.1 & Batang \\
12 & L3.4.2 & Batang \\
13 & L3.4.3 & Coccus \\
14 & L3.4.4 & Coccus \\
15 & L3.4.5 & Coccus \\
16 & L3.3.1 & Coccus \\
17 & L3.3.2 & Batang \\
18 & L3.3.3 & Batang \\
19 & L3.3.4 & Batang \\
20 & L3.3.5 & Coccus \\
\hline
\end{tabular}

Tahapan seleksi pada media padat MRS agar dilakukan dengan menambahkan compactin dan lovastatin berturut turut $150 \mu \mathrm{g} / \mathrm{mL}$ dan $2 \mathrm{mg} / \mathrm{mL}$. Pada tahapan ini diperoleh 20 isolat dengan karakteristik koloni yang berbeda beda. Pengamatan lebih lanjut terhadap ke-20 koloni yang berbeda menunjukan morfologi bakteri yang beragam seperti yang terlihat pada Tabel 3. Dari 20 koloni yang diisolasi, 13 koloni merupakan bakteri berbentuk coccus dan sisanya batang. Beberapa bakteri penghasil statin diketahui berbentuk batang berfilamen maupun coccus (Park dkk., 2003).

\section{Analisis Produksi Statin}

Analisis terhadap kandungan statin (lovastatin dan compactin) dari ke-20 isolat yang resisten terhadap compactin dan lovastatin menunjukkan hasil yang beragam. Kemampuan produksi statin oleh isolat yang bersifat resisten terhadap compactin dan lovastatin dapat dilihat pada Gambar 1.

Tidak semua isolat bakteri yang resisten terhadap compactin/lovastatin mampu memproduksi statin (compactin dan lovastatin) (Gambar 1). Kandungan statin terbesar secara berturut-turut diproduksi oleh isolat bakteri C3.3.5; C3.4.2; L3.3.3.; L3.3.4; dan C3.4.4. Faktor utama yang menyebabkan mikroorganisme mampu membentuk statin adalah adanya gen penyandi statin. Faktor lain yang mempengaruhi produksi statin adalah kondisi kultur meliputi $\mathrm{pH}$, surfactant dan komposisi media (Barrios-Gonzales dan Miranda, 2010). Aspergillus terreus memproduksi lovastatin secara optimal pada inkubasi dengan suhu $30^{\circ} \mathrm{C}$; $\mathrm{pH} 8,5$; glukosa sebagai sumber karbon, dan metionin sebagai sumber asam amino pembentuk lovastatin (Osman dkk., 2011). Penicillium brevicompactum optimum memproduksi compactin pada kondisi inkubasi suhu $25^{\circ} \mathrm{C}$; penambahan gliserol $22 \%$ sebagai sumber karbon; dan pH 6,5 (Shaligram dkk., 2009). Screning bakteri penghasil pravastatin optimum dilakukan pada media basal dengan mannitol 7\% sebagai sumber karbon; $\mathrm{pH} 7,2$; suhu $28^{\circ} \mathrm{C}$ (Chen dkk., 2006).

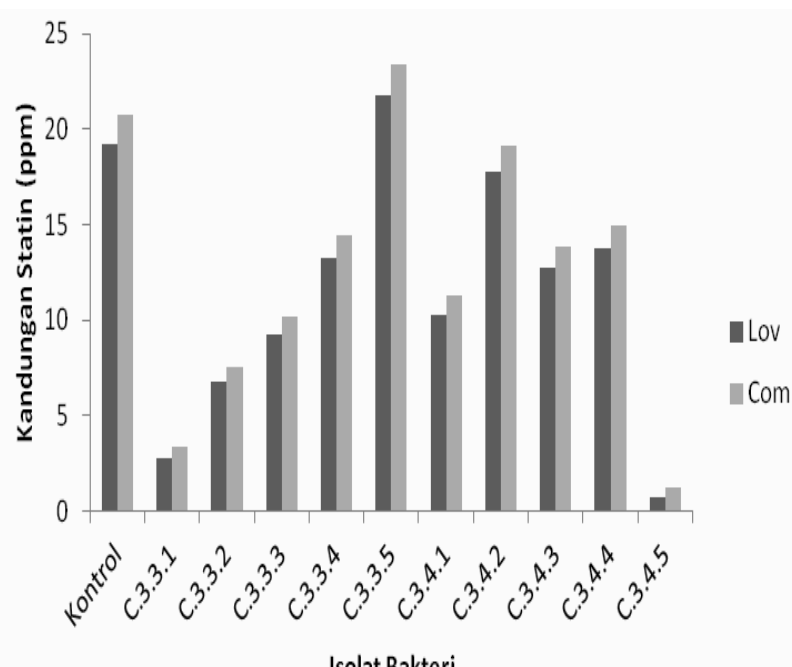

Gambar 1. Kandungan statin (lovastatin dan compactin) isolat bakteri dari bekasam (analisis menggunakan spektrofotometer) 
Data analisis statin menggunakan spektrofotometer pada panjang gelombang $238 \mathrm{~nm}$ menunjukan bahwa besarnya kadar lovastatin dan compactin pada setiap kultur bakteri hampir sama. Ini menunjukan bahwa lovastatin dan compactin dapat terdeteksi secara baik pada panjang gelombang yang sama $(238 \mathrm{~nm})$. Oleh karena itu, dilakukan analisis statin menggunakan HPLC untuk lebih mengetahui keberadaan statin yang sebenarnya, yaitu lovastatin ataupun compactin. Hasil analisis statin menggunakan HPLC dari 5 isolat yang potensial menghasilkan statin dapat dilihat pada Tabel 4.

Tabel 4. Hasil analisis statin menggunakan HPLC dari 5 isolat bakteri yang potensial memproduksi statin

\begin{tabular}{ccccccc}
\hline & \multicolumn{3}{c}{ Lovastatin } & \multicolumn{3}{c}{ Compactin } \\
\cline { 2 - 7 } $\begin{array}{c}\text { Isolat } \\
\text { bakteri }\end{array}$ & $\begin{array}{c}\text { Waktu } \\
\text { retensi } \\
\text { standar }\end{array}$ & $\begin{array}{c}\text { Waktu } \\
\text { retensi }\end{array}$ & $\begin{array}{c}\text { Kosentrasi } \\
\text { Lovastatin } \\
(\mathrm{ppm})\end{array}$ & $\begin{array}{c}\text { Waktu } \\
\text { retensi } \\
\text { standar }\end{array}$ & $\begin{array}{c}\text { Waktu } \\
\text { retensi } \\
\text { sampel }\end{array}$ & $\begin{array}{c}\text { Kosentrasi } \\
\text { Compactin } \\
(\mathrm{ppm})\end{array}$ \\
\hline C335 & 4,234 & 4,181 & 0.065 & 1,512 & - & 0 \\
C342 & 4,234 & 4,301 & 1.536 & 1,512 & - & 0 \\
L333 & 4,234 & 4,309 & 0.04 & 1,512 & - & 0 \\
L334 & 4,234 & 4,311 & 9.491 & 1,512 & - & 0 \\
C344 & 4,234 & - & 0.00 & 1,512 & - & 0 \\
\hline
\end{tabular}

Pada Tabel 4 dapat dilihat bahwa lovastatin dapat terdeteksi pada semua isolat kecuali C344, namun compactin tidak bisa terdeteksi pada panjang gelombang $238 \mathrm{~nm}$. Ini menunjukan bahwa jenis statin yang diproduksi oleh isolat bakteri dari bekasam adalah lovastatin. Kandungan lovastatin yang diproduksi oleh isolat dari bekasam jauh lebih kecil bila dibandingkan produksi statin dari kapang yang berasal dari angkak merah (Danuri, 2008). Osman dkk. 2011, menyatakan bahwa produksi lovastatin dari Aspergillus terreus pada awalnya adalah 54,5 ppm namun setelah dilakukan optimalisasi, produksi lovastatin meningkat menjadi 188,3 ppm. Oleh karena itu, diperlukan optimalisasi dengan berbagai perlakuan untuk meningkatkan produksi lovastatin. Meskipun demikian isolat bakteri penghasil statin dari bekasam dapat digunakan lebih lanjut untuk meningkatkan kandungan statin dari bekasam dan dapat dikembangkan sebagai pangan fungsional dalam menurunkan kolesterol darah.

\section{Penghambatan Bakteri Terhadap Enzim HMGR}

Analisis terhadap kemampuan inhibisi hasil metabolit bakteri dari bekasam menunjukan bahwa tiga isolat bakteri mampu menghambat aktivitas enzim HMGR. Isolat L3.3.4 merupakan bakteri dengan kemampuan terbesar dalam menghambat enzim HMGR yaitu sebesar 66,67\%, disusul oleh isolat bakteri C3.4.2 (58.33\%) dan C3.3.5 (25,00\%), sedangkan isolat L3.3.3 dan C3.4.4 tidak menunjukkan adanya penghambatan. Daya inhibisi isolat bakteri sejalan dengan kandungan lovastatin yang ada. Kandungan lovastatin pada L3.3.4 (9.491 ppm) paling tinggi bila dibandingkan dengan bakteri lainnya, disusul oleh isolat bakteri C3.4.2 (1,536 ppm).

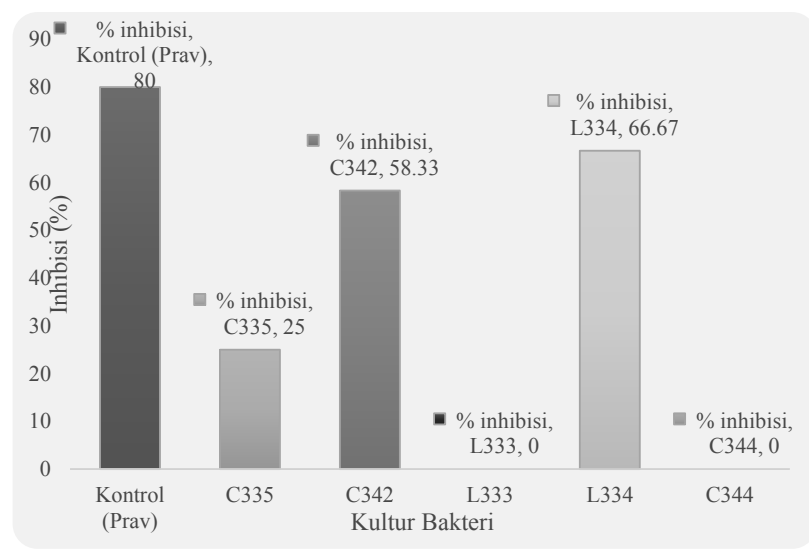

Gambar 2. Daya inhibisi isolat bakteri dari bekasam terhadap aktivitas enzim HMGR

Daya hambat isolat bakteri dari beksama masih lebih rendah dibandingkan dengan kontrol (pravastatin). Hal ini disebabkan karena pravastatin yang digunakan merupakan pravastatin komersil (Sigma Aldrich) yang murni. Meskipun demikian, terdapat 2 isolat bakteri yang memiliki daya hambat diatas 50\%. Kecilnya kandungan statin dari isolat bakteri $(<10$ ppm) tidak sebanding dengan daya hambat yang dimiliki oleh isolat L3.3.4 dan C3.4.2, sehingga dimungkinkan ada komponen bioaktif lain yang mendukung aktivitas penghambatan lovastatin terhadap enzim HMGR. Selain statin, peptida juga terbukti menghambat aktivitas HMGR, meskipun daya hambatnya sebesar 0,05\% (Kato dkk., 2009).

\section{Morfologi dan Identifikasi Bakteri Penghasil Lovastatin}

Uji terhadap morfologi isolat bakteri L3.3.4 menunjukkan bahwa isolat L3.3.4 dan C3.4.2 merupakan bakteri gram positif, berbentuk batang tidak berspora, katalase negatif, tidak motil dan tumbuh baik pada suhu $30-37{ }^{\circ} \mathrm{C}$. Hasil fermentasi gula menggunakan API $\mathrm{CH} 50$ dan $\mathrm{CHL}$ mengindikasikan bahwa isolat L3.3.4 adalah Lactobacillus acidophilus dengan nilai identik 99\%. Adapun isolat C3.4.2 merupakan Lactobacillus delbruckii sp. delbruckii (identik $89,7 \%$ ). Kedua bakteri termasuk dalam golongan bakteri asam laktat. Bakteri asam laktat merupakan golongan bakteri yang mendominasi pada produk-produk fermentasi ikan seperti bekasam (Desniar, 2012).

Penemuan bakteri asam laktat (Lactobacillus acidophilus dan Lactobacillus delbruckii sp. Delbruckii) 
yang menghasilkan komponen metabolit penghambat enzim HMGR (statin) merupakan sebuah kebaruan. Selama ini statin dihasilkan oleh beberapa kapang seperti Aspergillus terreus, Penicillium brevicompactum dan bakateri yaitu Streptomyces roseochromogenus, S. carbophilus, S. halstedii, Actinomadura sp., Streptomyces sp., serta Bacillus megaterium (BarriosGonzales dan Miranda, 2010).

\section{KESIMPULAN}

Seleksi terhadap 20 isolat yang resisten terhadap statin menghasilkan lima isolat potensial penghasil statin dan penghambat aktivitas enzim HMGR. Seleksi lebih lanjut menghasilkan dua bakteri penghasil statin dari bekasam yang memiliki daya hambat terbaik terhadap aktivitas enzim HMGR yaitu Lactobacillus acidophilus dan Lactobacillus delbruckii sp. delbruckii dengan daya hambat masing-masing $66,67 \%$ dan $58,33 \%$.

\section{UCAPAN TERIMA KASIH}

Ucapan terima kasih disampaikan kepada Direktorat Jenderal Perguruan Tinggi, melalui program Hibah Bersaing 2013-2014 atas pendanaan yang diberikan melalui kontrak No. 114a/U N9.3.1/PL/2013.

\section{DAFTAR PUSTAKA}

Abe, Y., Suzuki, T., Ono, C., Iwamoto, K., Hosobuchi, M. dan Yoshikawa, H. (2002). Molecular cloning and characterization of an ML-236B (compactin) biosynthetic gene cluster in Penicillium citrinum. Molecular Genetics and Genomics 267: 636-646.

Burg, J.S. dan Espenshade, P.J. (2011). Regulation of HMGCoA reductase in mamals and yeast. Progress in Lipid Research 50: 403-410.

Barrios-González, J. dan Miranda, R.U. (2010). Biotechnological production and applications of statins. Applied Microbiology and Biotechnology 85: 869-883.

Chakravarti, R. dan Sahai, V. (2004). Compactin-a review. Applied Microbiology and Biotechnology 64: 618-624.

Chen, C.H., Hu, H.Y., Cho, Y.C. dan Hsu, W.H. (2006). Screening of compactin resistant microorganisms capable of converting compactin to pravastatin. Current Microbiology 53: 108-112.

Danuri, H. (2008). Optimizing angkak pigments and lovastatin production by Monascus purpureus. Hayati Journal of Bioscience 15(2): 61-66.
Delima, L., Mihardja dan Siswoyo, H. (2009). Prevelansi dan faktor determinan penyakit jantung di Indonesia. Buletin Penelitian Kesehatan 37(3): 142-159.

Desniar, Rusmana, I., Suwanto, A. dan Mubarik N.R. (2012). Senyawa antimikrobia yang dihasilkan dari mikroorganisme bekasam. Jurnal Akuatik 3(2): 135-145.

Harsha, N., Subarao, S., Sridevi, V., Lakshmi, M.V.V.C. dan Kiran, T.K. (2013). Production of mevastatin by solid state fermentation using sesame oil cake. Research journal of Pharmaceutical, Biology and Chemical Science 4(1): 459-436.

Kato, M., Ogawa, H., Kishida, T. dan Ebihara, K. (2009). The mechanism of the cholesterol-lowering effect of waterinsoluble fish protein in ovariectomised rats. British Journal of Nutrition 102: 816-824.

Kirana, C., Rogers, P.F., Bennett, L.E., Abeywardena, M.Y. dan Patten, G.S. (2005). Rapid screening for potential cholesterol-lowering peptides using naturally derived micelle preparation. Australian Journal Dairy Technology 60(2): 163-166.

Lachenmeier, D.W., Monakhova, Y.B., Kuballa, T., Behrends, S.L., Maixner, S., Himmelsheher, M.K., Waldner, A. dan Steffen, C. (2012). NMR evaluation of total statin content and HMG-CoA reductase inhibition in red yeast rice food supplements. Chinese Medicine 7(8): 1-7.

Osman, M.E., Khattab, O.H, Zaghlol, G.M. dan Abd ElHameed, R.M. (2011). Optimization of some physical and chemical factors for lovastatin productivity by local strain of Aspergillus terreus. Australian Journal of Basic and Applied Sciences 5(6): 718-732.

Park. J.W., Lee, J.K, Kwon, T.J., Yi, D.H, Kim, Y.J, Moon, S.H, Suh, H.H, Kang, S.M. dan Park, Y.I. (2003). Bioconversion of compact in into pravastatin by Streptomyces sp. Biotechnology Letters 25: 1827-1831.

Rinto, Baehaki, A. dan Suhartono, M.T. (2013). Potency of bekasam as cholesterol reduction agent. Proceeding of International Symposium on Aquatic Products Processing 2013. Bogor 13-15 Nov 2013.

Shaligram, S., Singhal, S.K., Panday, A. dan Szakeas, G. (2009). Compactin production studies using Penicillium brevicompactum under solid-states fermentation condition. Applied Biochemistry and Biotechnology 159: $505-520$.

Zhuge, B., Fang, H.Y., Yu, H., Rao, Z.M., Shen, W., Song, J. dan Zhuge, J. (2008). Bioconversion of lovastatin to a novel statin by Amycolatopsis sp. Applied Microbiology and Biotechnology 79: 209-216. 